\title{
EVALUATION OF SILVER CARP FRY TRANSPORTATION METHODS ON WATER QUALITY AND SURVIVAL RATIO
}

Abdel Aal, E. I. ${ }^{1}$, Kishta, A. M. ${ }^{1}$, Radwan M. E. ${ }^{2}$ and M. M. Soliman ${ }^{2}$

ABSTRACT

The effect of stocking densities (30,60, 90, and $120 \mathrm{~g} / \mathrm{l})$, durations of transportation (2, 4, and 6 hours), with two methods of aeration (pure oxygen and atmospheric air)in three different containers shapes (polyethylene bags, cylindrical and cuboids) on silver carp fry, and water quality parameters was tested. Water samples were taken at $2 \mathrm{~h}$ intervals after transport to determine oxygen concentration, $p H$, and total ammonia concentration. Oxygen concentration adjusted to 8 ppm for all treatments at transport start of silver carp fries. The results revealed that both water quality and survival ratio were affected by method of transportation. Oxygen concentration, $\mathrm{pH}$ values, ammonia concentration and survival ratio measured in pure oxygen supply were significantly $(P<0.05)$ higher compared to those measured in atmospheric air supply under all treatments. The oxygen concentration of silver carp fry transportation was in the range of 0.67 to $7.11 \mathrm{mg} /$, and the stocking densities from 30 to $120 \mathrm{~g} / \mathrm{l}$. Transportation durations significantly affected the oxygen concentration under closed system (polyethylene bags) and open system (cylindrical and cuboids containers). The $\mathrm{pH}$ values of the water during silver carp fry transportation were in the range of 6.35 to 7.2, and the lowest ph value of 6.35 was recorded at $30 \mathrm{~g} / \mathrm{l}$ stocking density, 2 h duration of transportation, pure oxygen supply and polyethylene bags containers. The ammonia concentration values of silver carp fry transportation was in the range of 1.1 to $7.0 \mathrm{mg} /$, and the lowest ammonia value of $1.1 \mathrm{~g} / \mathrm{l}$ was recorded at $30 \mathrm{~g} / \mathrm{l}$ stocking density, $2 \mathrm{~h}$ duration of transportation, pure oxygen supply and polyethylene bags container. The lowest survival ratio of silver carp fry transportation value

\footnotetext{
${ }^{1}$ Assist. Prof. of Agric. Eng., Dept. of Agric. Eng., Fac. of Agric. Zagazig University.

${ }^{2}$ Researcher and Research Assist., Central Lab. For Aquaculture Research.
} 
of $14.97 \%$ was recorded at $120 \mathrm{~g} / \mathrm{l}$ stocking density, atmospheric air supply with $6 \mathrm{~h}$ duration of transportation, and the highest survival ratio value of $97.13 \%$ was recorded at $30 \mathrm{~g} / \mathrm{l}$ stocking density, $2 \mathrm{~h}$ duration of transportation, pure oxygen supply and polyethylene bags containers. The lowest cost value of silver carp fry transportation of 0.09 L.E per $5 \mathrm{~g}$. for live fry was recorded at $120 \mathrm{~g} / \mathrm{l}$ stocking density, $2 \mathrm{~h}$ duration of transportation, pure oxygen supply and polyethylene bags containers, but then, the highest cost value of silver carp fry transportation of 0.92 L.E. per $5 \mathrm{~g}$. for live fry was recorded at $30 \mathrm{~g} / \mathrm{l}$ stocking density, $6 \mathrm{~h}$ duration of transportation, atmospheric air supply with polyethylene bags containers. From the obtained results, the best parameters of silver carp fry transportation methods could be transport with stocking density of (30 $g / l)$, duration of transportation of (2 hours), methods of aeration of pure oxygen supply, and container shape of polyethylene bags to achieve the highest values of oxygen concentration and the survival ratio and the lowest values of the $\mathrm{pH}$ value, ammonia concentration and total cost.

Key words: fry transportation, silver carp, aeration, survival ratio, polyethylene bags, transport in containers, water quality.

\section{INTRODUCTION}

$\mathrm{T}$

The need for rapid development and proper management of the fish farms is becoming a necessity in view of the high demand for fish compensate for the present deficiency of the other animal protein sources (Hamza 1988). Fish contains a good quantity of protein, about $18-20 \%$ and fat content ranges from $0.2 \%$ to $25 \%$. Fish is a rich source of vitamins, particularly vitamins $\mathrm{A}$ and $\mathrm{D}$ from fatty species. The minerals present in fish include iron, calcium, zinc, iodine (from marine fish), phosphorus, selenium and fluorine.

Fish culture embodies in land and coastal water, but in fact, the inland culture is greater than the coastal culture. Inland fish culture embodies fresh water and brackish water. Fresh water fish culture (about 40,000 faddans) is much more developed in Egypt than brackish water fish culture (20,000 faddans) (Hamza 1988). 
Total fish production in Egypt is about 970,000 tons according to Ministry of Agriculture, 2007. 375,000 tons (38.72\%) are from fisheries, 595,000 tons $(61.28 \%)$ are from aquaculture.

There are two basic transport systems for live fish, the closed system and the open system. The closed system is a sealed container in which all the requirements for survival are self-contained. The simplest of these is a sealed plastic bags partly filled with water and oxygen. The open system consists of water-filled containers in which the requirements for survival are supplied continuously from outside sources. The simplest of these is a small tank with an aerator stone.

The bags used for fish transport in water with oxygen are produced in a number of modifications. They are manufactured from a thin or thicker transparent polyethylene foil and usually have the shape of sack or sleeve. The water to be used for fry transport in a bag should comply with all requirements.

The transport in tank should be done under the conditions of constant air or oxygen supply. This is very important to the welfare of fish even if dissolved oxygen content of water seems to be satisfactorily high in tank. The weight of fish that can be safely transported in a tank depends on the efficiency of the aeration system, duration of the transport, water temperature, fish size and fish species, some calculations of loading rates for various fish species are presented by (Piper et al. 1982).

Boyd and Watten (1989) stated that two basic methods are used for increasing dissolved oxygen (DO) concentrations in water. Air-contact aeration systems increase the area of the air-water interface and the degree of turbulence in water to enhance the absorption of oxygen from the atmosphere or from rising air bubbles. Also Golombieski et al. (2003) showed that when fish is transported in a closed system, an oxygen deficit may occur when the load density is high and the transport is prolonged. The dead fish also compete with the living ones for oxygen. The increased bacterial multiplication requires oxygen and this multiplication may further produce toxic metabolites and stated that, an oxygen deficit was observed at $20^{\circ} \mathrm{C}$ and $25^{\circ} \mathrm{C}$ at the load density of $168 \mathrm{~g} / \mathrm{l}$, since the 
dissolved oxygen levels approached near zero. There was fingerling mortality at this density, and bacteria that degrade dead fish probably also consumed oxygen, contributing to reducing these levels in the water. The use of pure oxygen in the bags increased the dissolved oxygen levels in the water up to saturation in relation to the partial pressure of oxygen contained in the bags, Gomes et al. (1999). Lawson (1995) recommended a minimum criterion of $6.0 \mathrm{mg} / \mathrm{l}$ dissolved oxygen for all juvenile fish and crustaceans. Practically all species can survive for short period at dissolved oxygen concentration less than optimum, and they are more susceptible to infectious diseases. Respiration of common carp and silver carp decreased when this species were exposed to ammonia concentration of the range 0.2 to $1.0 \mathrm{mg} / \mathrm{l}$, (Nemcosk et al. 1984).

Chona and Marietta (2003) said that the best packing density for transport of grouper larvae is 50 larvae/l and that packing density could be increased to a maximum of 100 larvae/l when transported at $23^{\circ} \mathrm{C}$. Also Pavlidisa et al. (2003) suggested that red porgy should be transported in stocking densities of $20-25 \mathrm{~g} / \mathrm{l}$ and at a hauling temperature similar to that kept at the exporter's fish rearing tanks (preferable $19^{\circ} \mathrm{C}$ ).

Ng et al. (1992) found that $16 \%$ to $18 \%$ mortality might occur to Cyprinus carpio when unionized ammonia concentration was 0.9 to 1.3 $\mathrm{mg} / \mathrm{l}$. The term total ammonia refers to the sum of unionized ammonia $\left(\mathrm{NH}_{3}\right)$ and ionized ammonia $\left(\mathrm{NH}_{4}\right)$. Ammonia induces detrimental changes in tissue structure, cell function, blood chemistry, osmoregulation and disease resistance. A sharp peak in ammonia excretion of sockeye salmon was observed by Thurston et al. (1981) $4 \mathrm{~h}$ after single feeding. Low dissolved oxygen concentrations increase the toxicity of ammonia to fish. Boyd (1982) showed that water $\mathrm{pH}$ was reduced in the first hours of transport because the production of carbon dioxide due to fish respiration led to the formation of carbonic acid, which can dissociate into $\mathrm{H}^{+}$and $\mathrm{HCO}_{3}{ }^{-}$, and most natural waters have $\mathrm{pH}$ values between 6.5 and 9.0.

From the previous introduction, there is a shortage in literature concerning fry transport especially the optimum conditions required for a successful transport operation. In this paper, some of the important 
parameters affecting the transportation process will be investigated to conclude the optimum transport conditions.

The objectives of this study will include investigation the effect of transport durations, stocking densities, transport containers' shape and aeration systems on silver carp fry survival ratio and water quality during transportation.

\section{MATERIALS AND METHODS}

This study was carried out in Central Laboratory for Aquaculture Research, Abbassa, Abou-Hammad, Sharkia during the year of 2009.

Transport fry in open system and closed system at different densities of silver carp Hypophthalmic molitrix were used to evaluate some study parameters on water quality and survival of fry during journey. The study included two methods of aeration (pure oxygen and atmospheric air); four stocking densities $(30,60,90$, and $120 \mathrm{~g} / \mathrm{l})$; three different containers shapes (polyethylene bags, cuboids, and cylindrical); and three transport durations $(2,4$, and 6 hours) with average truck speed $35 \mathrm{~km} / \mathrm{hr}$ on variety road between dirt and tarmac. A total of 72 treatments were suggested and implemented in 3 replicates each. Silver carp fries of $5.0 \mathrm{~g}$ average mass were used in different densities to investigate the previous parameters. Polyethylene bags were $0.6 \mathrm{~mm}$ thick and have the dimensions of $1.1 \times 0.35 \mathrm{~m}$. Cuboids containers are manufactured from plastic boards. They have dimensions of $0.31 \times 0.23 \times 0.185 \mathrm{~m}$ and thickness of $5.4 \mathrm{~mm}$, the height of water $13 \mathrm{~cm}$. Cylindrical containers are manufactured from plastic. They have dimensions of $0.37 \mathrm{~m}$ height, $0.19 \mathrm{~m}$ diameter, the height of water is $18 \mathrm{~cm}$.

Pure oxygen was provided by compressed oxygen cylinder and atmospheric air was supplied by a battery operated air pump which uses 2 batteries (size D, 1.5 Volts). Air dispensers are used to bubble air and pure oxygen in open systems and oxygen concentration adjusted to $8 \mathrm{ppm}$ for all treatment at transportation start and after to fill of containers with fries. The containers were hauled in a transportation truck for different transportation durations.

Water samples from each treatment were tested to determine 
concentration of dissolved oxygen (DO), $\mathrm{mg} / \mathrm{l}, \mathrm{pH}$, and total ammonia, $\mathrm{mg} / \mathrm{l}$, each two hours.

Dissolved oxygen was measured using Dissolved Oxygen Meter (YSI Model 58) and $\mathrm{pH}$ was assessed using $\mathrm{pH}$ meter. Total ammonia concentration was measured in laboratory using $\mathrm{HACH}$ Comparison Method. The survival ratio (SR) was calculated using the following equation:

$$
S R=\frac{M t-M d}{M t} \times 100
$$

Where: Mt : total mass of fry in the container, $g$.

Md : mass of dead fries in each container, $\mathrm{g}$.

The cost incurred by the truck was estimated using the following equation, (Awady 1978):

$$
C=\frac{P}{h}\left(\frac{1}{a}+\frac{i}{2}+t+r\right)+(0.9 \text { w.s.f })+L, \quad L E / h
$$

Where:

C: hourly cost, L.E, P: Capital investment (truck price $=100,000$ L.E)

h: yearly working hours (assumed $2500 \mathrm{~h} /$ year), a: life expectancy of the truck (assumed 20 years), i: interest rate/year (assumed 10\%), $\mathrm{t}$ : taxes, and overheads ratio (assumed 10\%), r: repairs and maintenance ratio (assumed 10\%), w: horsepower of the truck engine, $100 \mathrm{hp}$, s: specific fuel consumption, 0.24 l/h.hp

f: fuel price, 1.50 L.E/l, L: operator wage, 5.00 L.E/h, and, 0.9: factor to take lubrication and greasing into account.

Finally, the cost analysis was carried out in order to evaluate the transport unit economically and then compare between different methods. The total cost incurred by a treatment was estimated by the following equation:

Total cost $=$ truck cost + aeration cost + container cost + fry cost + labor cost 


\section{Statistical analysis}

Four measurements were done for oxygen concentration, $\mathrm{pH}$ value, ammonia and survival rate. The obtained data were statistically analyzed (univaraite analysis of variance)to determine the main and interaction effects between levels of stocking densities, methods of aeration, different containers' shapes; and transportation durations.

\section{RESULTS AND DISCUSSION}

The observed data were tabulated, analyzed, and plotted to investigate the effect of different study parameters.

\section{Effect of Different Parameters on Oxygen Concentration:}

The effect of changing the levels of stocking densities, methods of aeration, different containers shapes, and transportation durations on the oxygen concentration of silver carp fry transportation is shown in Fig. (1). Statistical analysis showed that increasing stocking density had significant effect $(\mathrm{p}<0.05)$ on the oxygen concentration under pure oxygen supply and atmospheric air supply but did not show any trend indicating that the interaction of stocking density with other component played an important role in the oxygen concentration of the fry transportation. It can be said that oxygen concentration in water was decreased with increasing stocking density due to the competition among fries. Also, increase the transportation duration had the most significant role in the oxygen concentration but the oxygen concentration measured in pure oxygen supply was higher than that measured in atmospheric air supply under all treatments. Oxygen concentration values measured in closed system (polyethylene bags) throughout 2 hours in stocking densities 30, 60, 90 and $120 \mathrm{~g} / 1$ were $7.12,4.75,3.00$, and $2.73 \mathrm{mg} / \mathrm{l}$ respectively under pure oxygen supply. In addition, the values were 3.10, $2.87,2.40$, and $1.97 \mathrm{mg} / \mathrm{l}$ respectively using atmospheric air supply. It is clear that the transportation period has affected the oxygen concentration. 
Pure oxygen

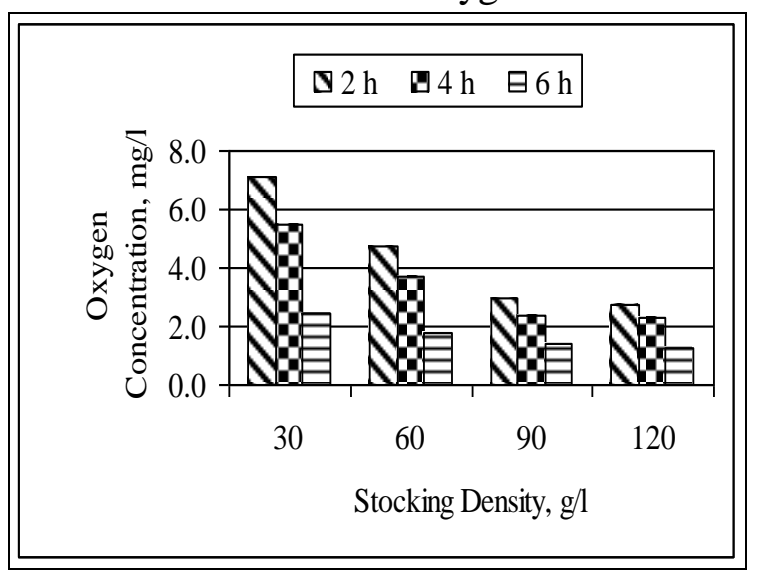

Atmospheric air

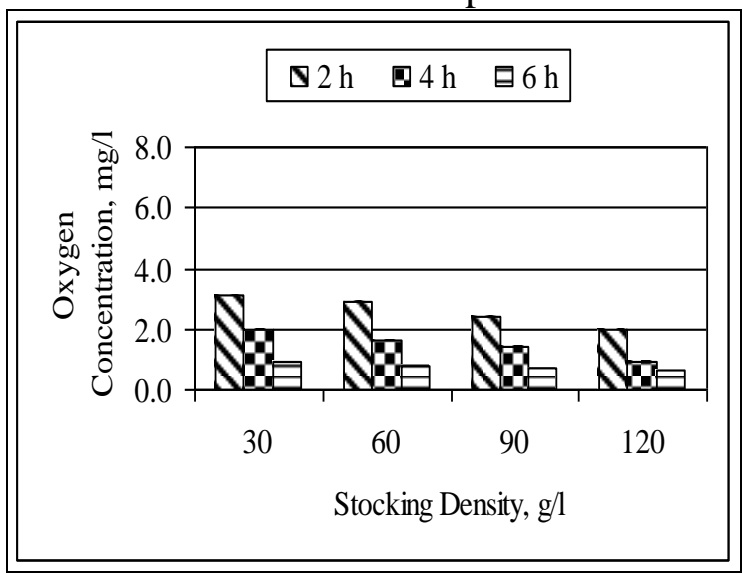

Polyethylene Bags.


Cylindrical Containers.
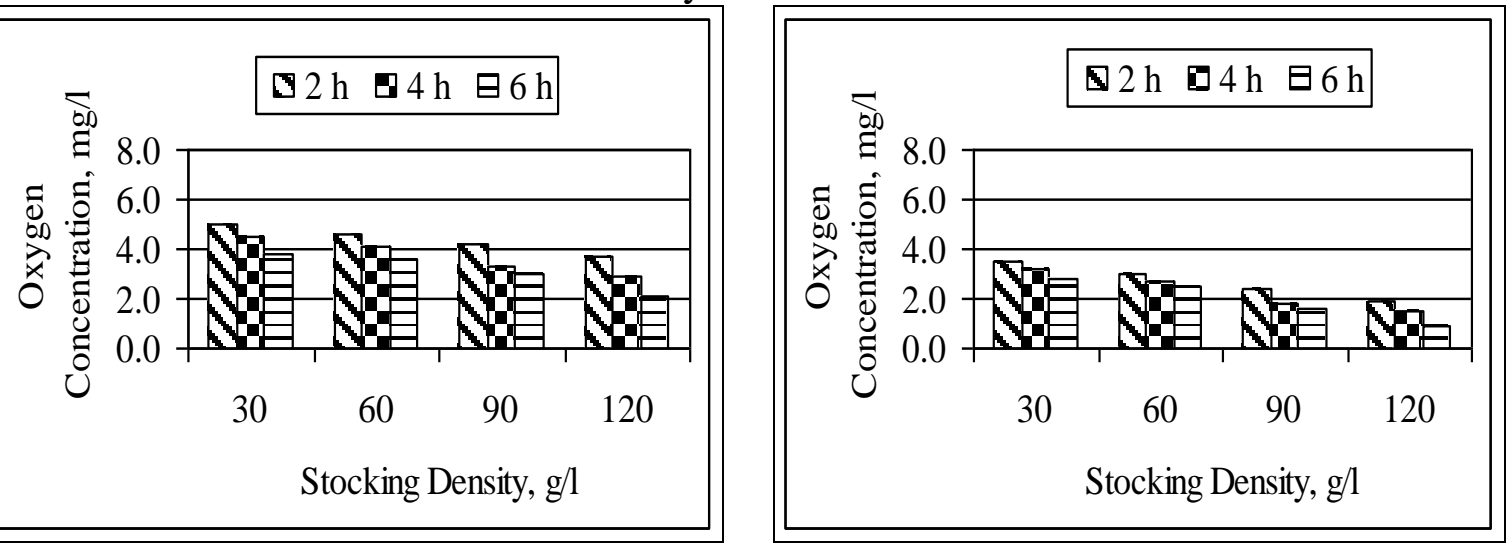

Cuboids Containers

Figure 1: Effect of study parameters on oxygen concentration with different containers shapes. 
Oxygen concentration that was measured throughout 2 and 4 hours in pure oxygen supply was higher than that measured at atmospheric air supply in the same treatment. These results are in agreement with those found by Golombieski et al. (2003) and Chona and Marietta (2003).

\section{Effect of Different Parameters on pH Value:}

The effect of changing the levels of stocking densities, methods of aeration, different containers shapes, and transportation durations on the $\mathrm{pH}$ values of silver carp fry transportation is shown in Fig. (2). Statistical analysis showed that increasing stocking density had significant effect ( $p$ $<0.05$ ) on the $\mathrm{pH}$ values but did not show any trend indicating that the interaction of stocking density with other component played an important role in the $\mathrm{pH}$ values of the fry transportation. As the stocking density was increased from 30 to $120 \mathrm{~g} / \mathrm{l}$, the $\mathrm{pH}$ values increased from 6.35 to 6.90 under pure oxygen supply in bags after $2 \mathrm{~h}$ transport duration. At the same time $\mathrm{pH}$ values increased from 6.71 to 7.05 using atmospheric air supply under the same conditions. It is also noticeable the $\mathrm{pH}$ values increased from 6.35 to 6.79 by increasing transport duration from 2 to $6 \mathrm{~h}$ under $30 \mathrm{~g} / \mathrm{l}$ stocking densities using pure oxygen. Same trend was found under different treatments using pure oxygen supply and atmospheric air supply. Pavlidisa et al. (2002) showed similar results. It is logical from the previous discussion to conclude that increasing stocking densities and transportation durations will increase the breathing activities which produce more $\mathrm{CO}_{2}$ which tends to increase water acidity. However, this effect was offset by increasing ammonia concentration which was produced by larger quantities by increasing stocking densities and transport durations.

\section{Effect of Different Parameters on Total Ammonia Concentration:}

The effect of changing the levels of stocking densities, methods of aeration, different containers shapes, and transportation durations on the ammonia concentration of silver carp fry transportation is shown in Fig. (3). Statistical analysis showed that the total ammonia concentration increased significantly $(\mathrm{P}<0.05)$ as the level of stocking densities and transport durations increased. The total ammonia concentration increased from 1.1 to $1.5 \mathrm{mg} / \mathrm{l}$ and from 2.8 to $3.5 \mathrm{mg} / \mathrm{l}$ by increasing the stocking density from 30 to $120 \mathrm{~g} / \mathrm{l}$ under both aeration systems through transport duration of $2 \mathrm{~h}$ respectively. Meanwhile it was increased from 1.1 to 2.3 $\mathrm{mg} / \mathrm{l}$ and from 2.8 to $5.1 \mathrm{mg} / \mathrm{l}$ by increasing the transport duration from 2 to $6 \mathrm{~h}$ under $30 \mathrm{~g} / \mathrm{l}$ 
Pure oxygen

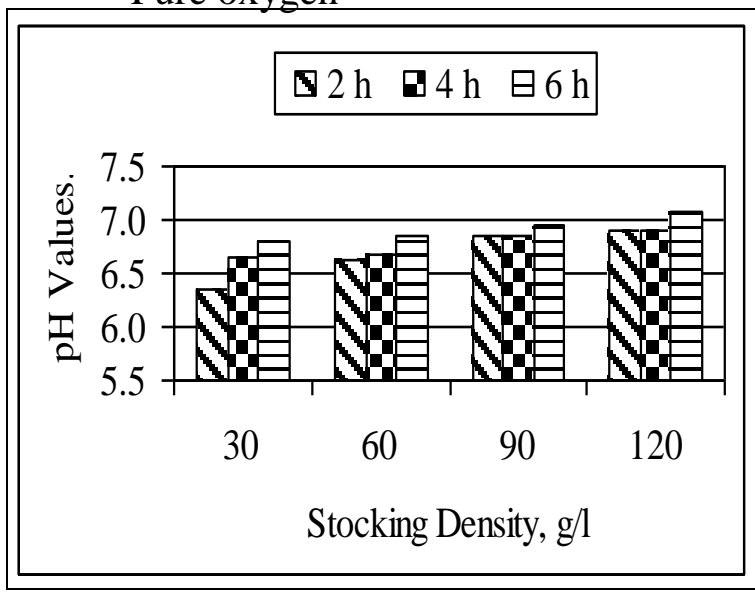

Atmospheric air

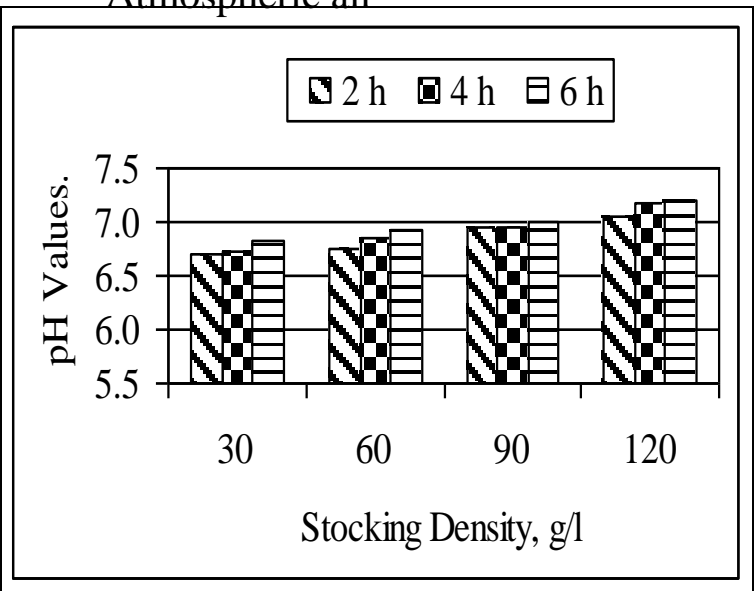

Polyethylene Bags.
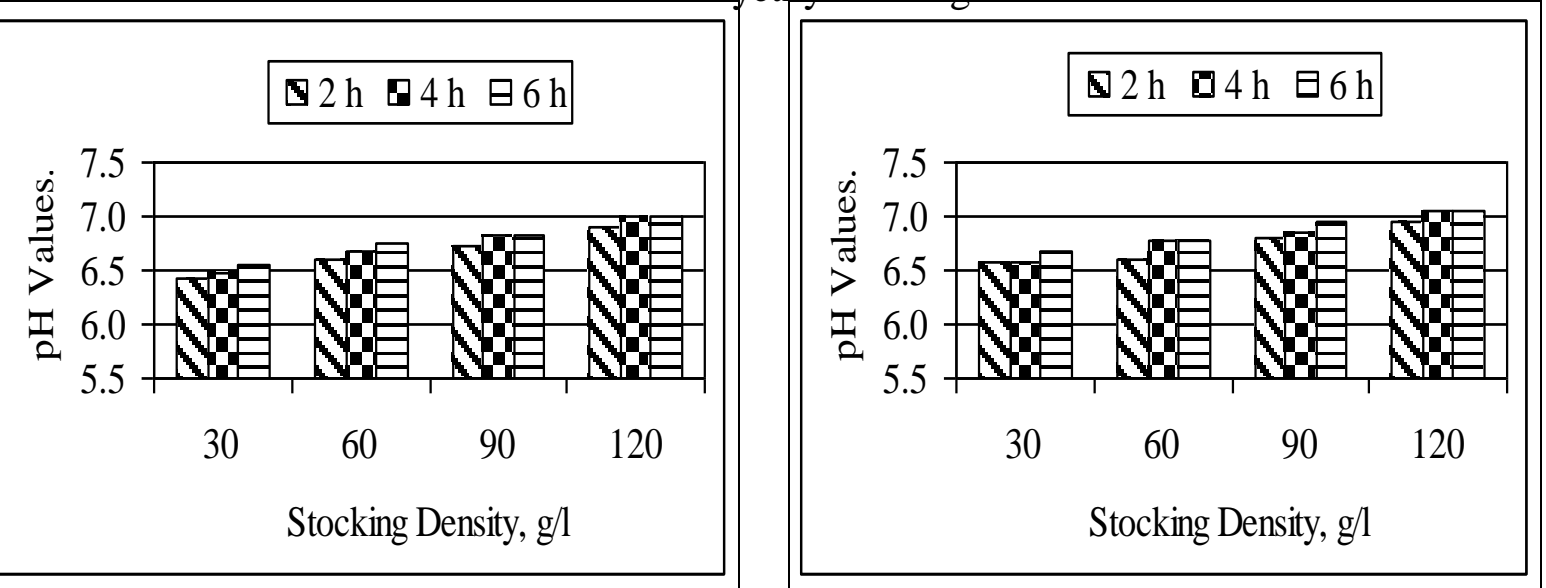

Cylindrical Containers.
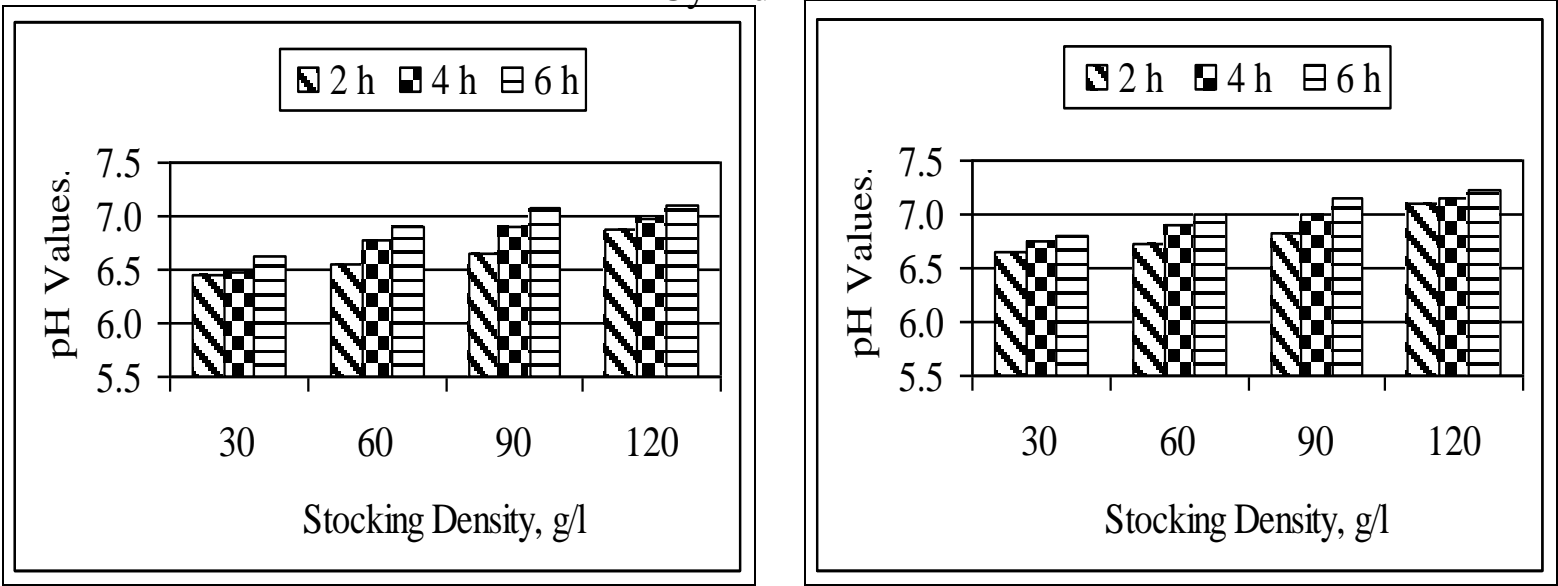

Cuboids Containers

Figure 2: Effect of study parameters on $\mathrm{pH}$ values with different containers shapes. 
Pure oxygen

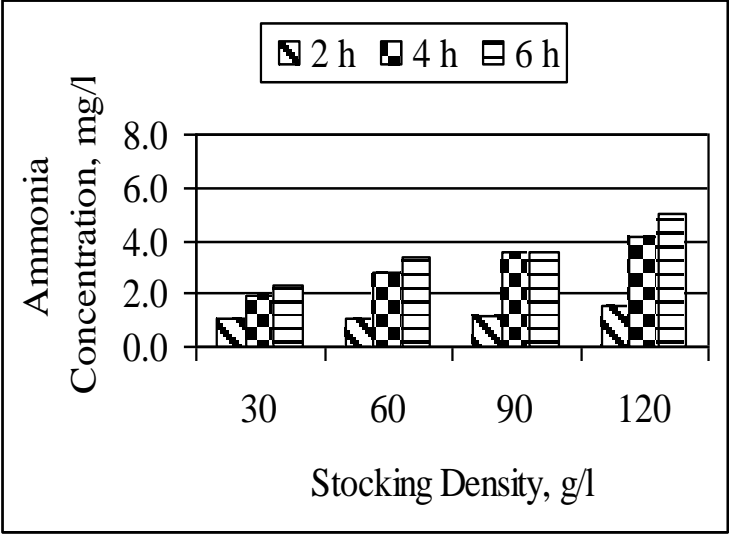

Atmospheric air

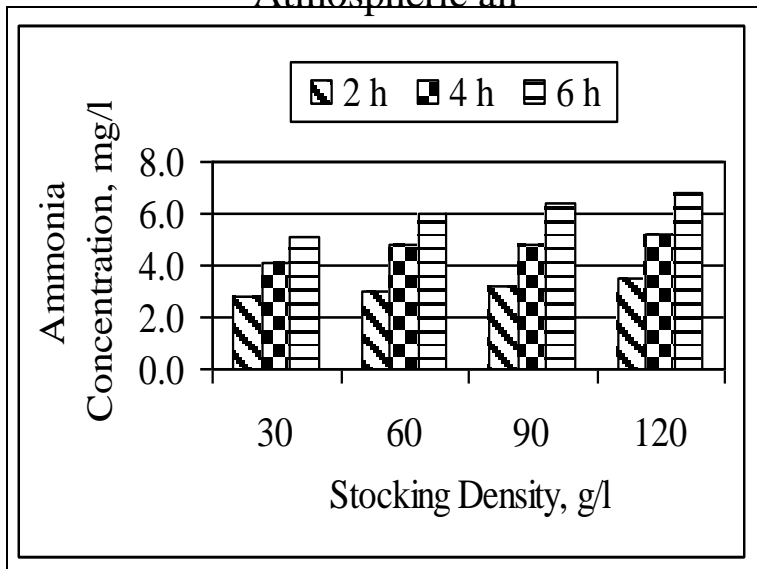

Polyethylene Bags.
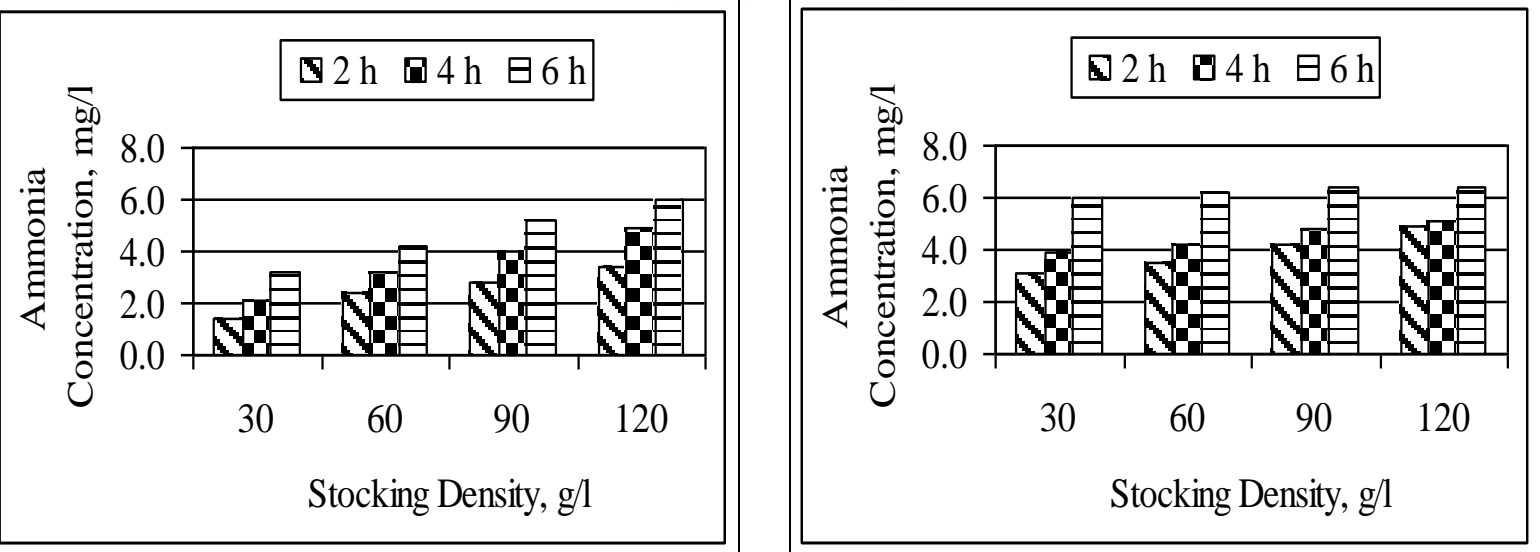

Cylindrical Containers.
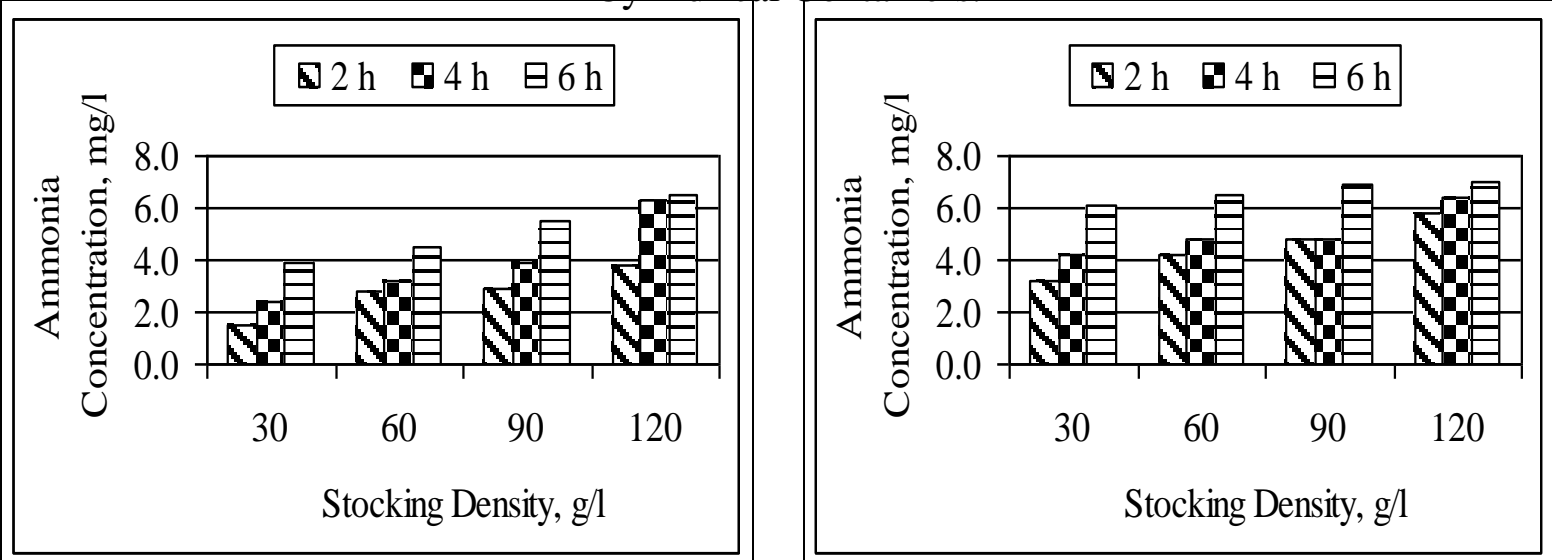

Cuboids Containers

Figure 3: Effect of study parameters on total ammonia concentration with different containers shapes. 
stocking density for both aeration systems. The highest ammonia concentration of $6.8 \mathrm{mg} / \mathrm{l}$ was recorded after $6 \mathrm{~h}$ of transportation at stocking density of $120 \mathrm{~g} / \mathrm{l}$ for the atmospheric air system in polyethylene bags. It was noticeable that ammonia concentration was higher under atmospheric air supply than that under pure oxygen supply at all stocking densities and transport durations. Accumulation of ammonia and its intermediate products in intensive culture system causes mortality. Ammonia is utilized as an energy source by autotrophic nitrifying aerobic bacteria, Nitrosomonas and Nitrobacter, which oxidize it to nitrite and nitrate, respectively.

\section{Effect of Different Parameters on Survival Ratio:}

The effect of changing the levels of stocking densities, methods of aeration, different containers shapes, and transportation durations on the survival ratio of silver carp fry transportation is given in Fig. (4). Statistical analysis showed that increasing stocking density had significant effect $(\mathrm{p}<0.05)$ on the survival ratio and as the stocking density was increased from 30 to $120 \mathrm{~g} / \mathrm{l}$, the survival ratio decreased from 87.73 to $76.61 \%$ and from 86.26 to $72.52 \%$ under both aeration systems for $2 \mathrm{~h}$ transport duration respectively. Meanwhile it was decreased from 87.73 to $75.90 \%$ and from 86.26 to $66.44 \%$ by increasing transport duration from 2 to $6 \mathrm{~h}$ at stocking density of $30 \mathrm{~g} / \mathrm{l}$ under both aeration systems respectively in cylindrical containers. In addition, survival ratio calculated in pure oxygen supply was higher than that calculated in atmospheric air supply. The survival ratio in polyethylene bags was higher than that obtained with cylindrical and cuboids containers, where survival ratio was in polyethylene bags $97.11 \%$, cylindrical containers $87.73 \%$ and cuboids containers $92.60 \%$ at $30 \mathrm{~g} / \mathrm{l}$ through $2 \mathrm{~h}$ with pure oxygen supply. This result can be attributed to the nervous behavior of the sliver carp fries during transportation and less solubility of oxygen in open systems.

\section{Cost Analysis:}

\subsection{Cost Analysis for Polyethylene Bags:}

Fig. 5 displays the cost incurred using polyethylene bags under different stocking densities, transport durations and aeration systems. It can be concluded that total cost associated with one bag transport is increasing by increasing transport duration. The cost incurred using atmospheric air supply was higher than that incurred using pure oxygen supply. 
Pure oxygen

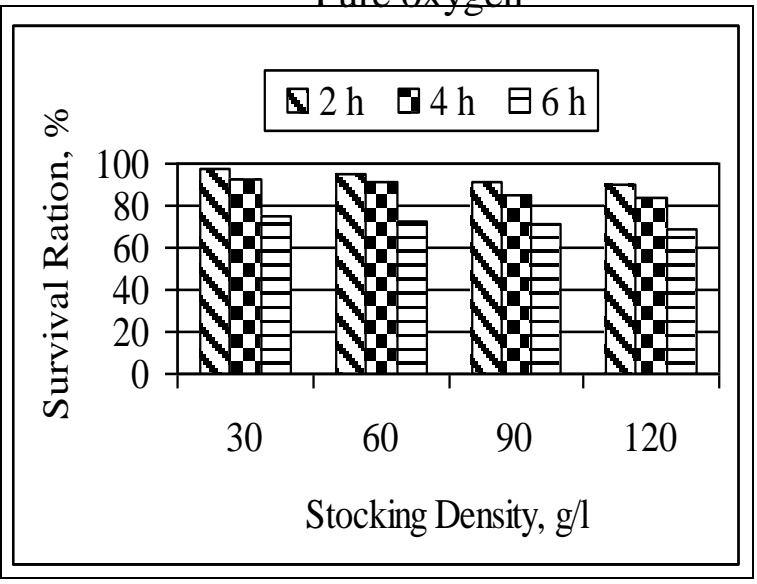

Atmospheric air

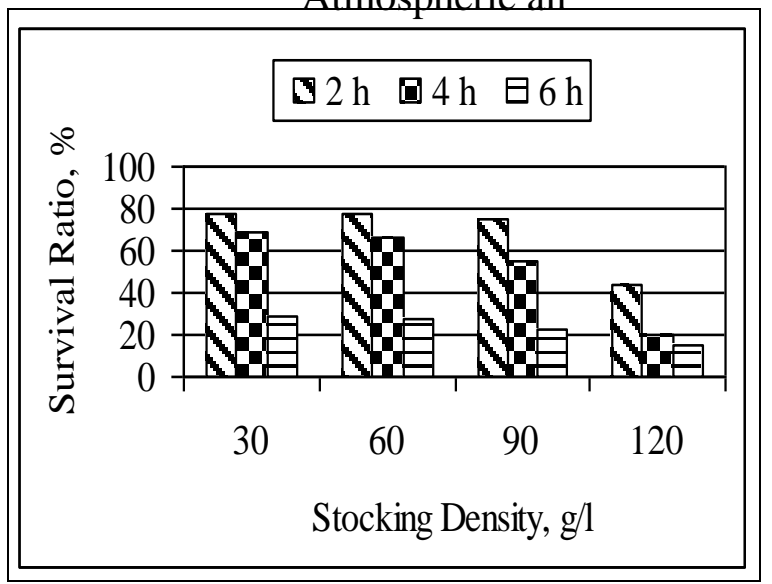

Polyethylene Bags.
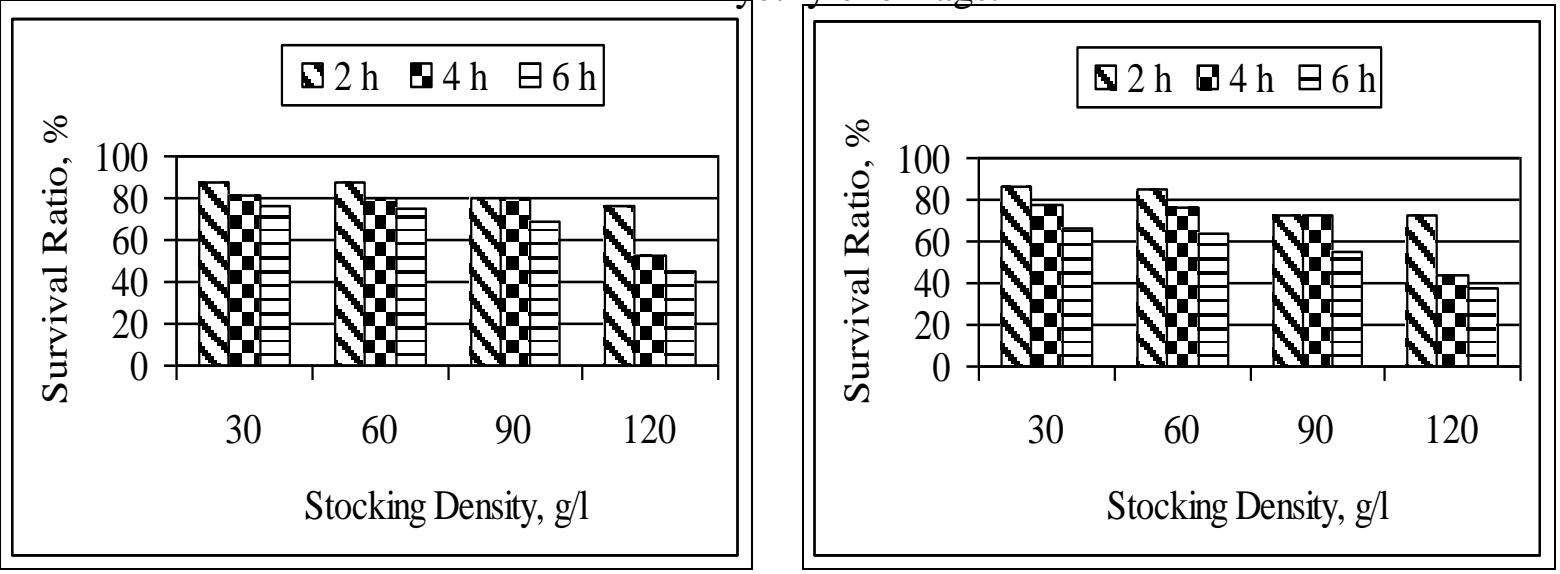

Cylindrical Containers.
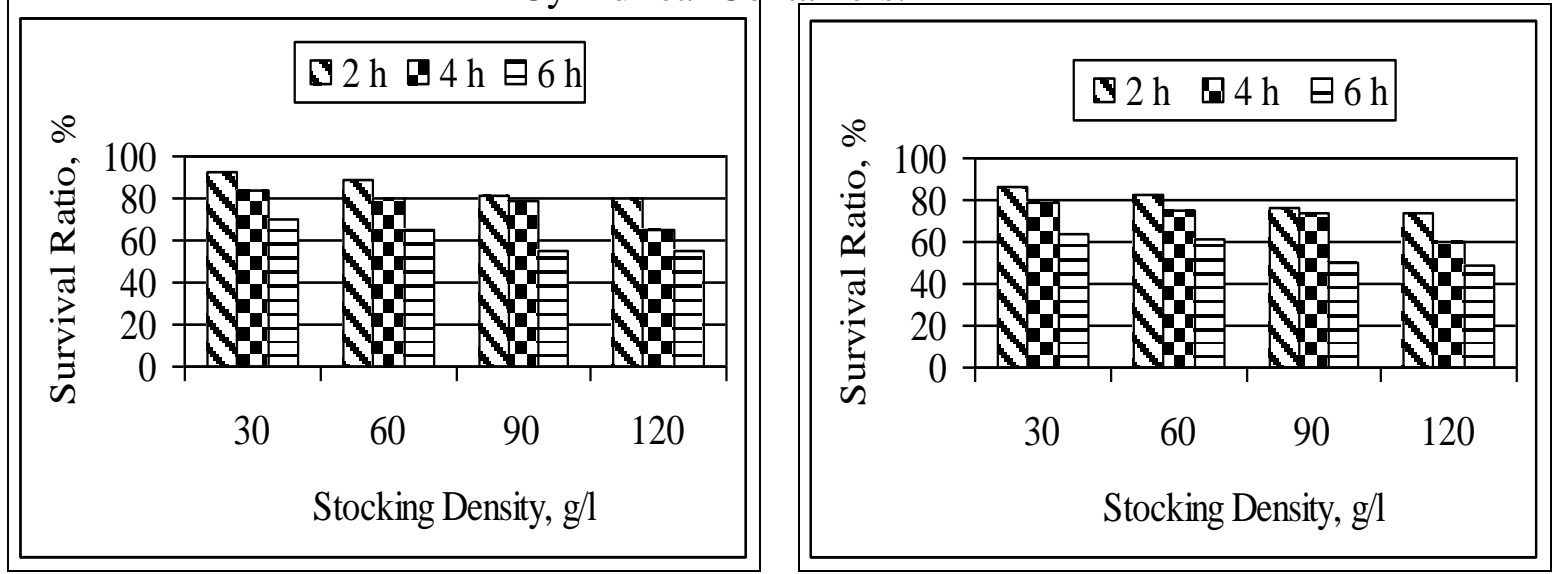

Cuboids Containers

Figure 4: Effect of study parameters on survival ratio with different containers shapes. 
pure oxygen

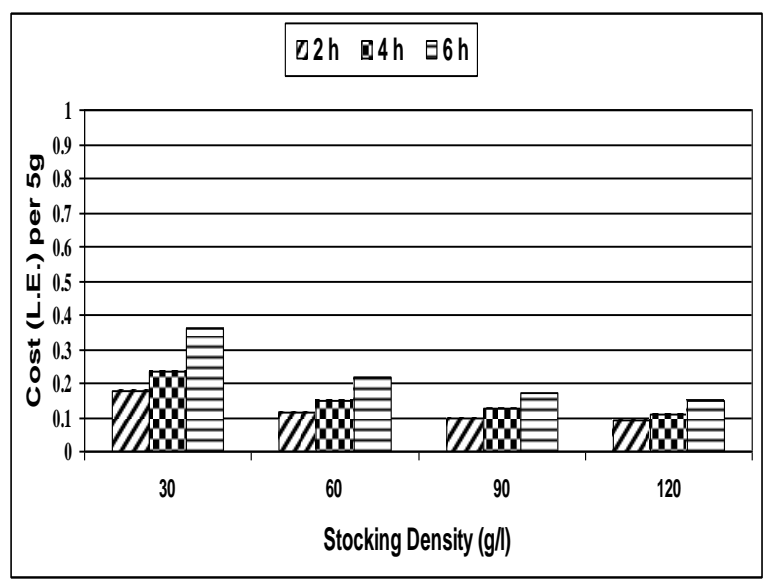

atmospheric air

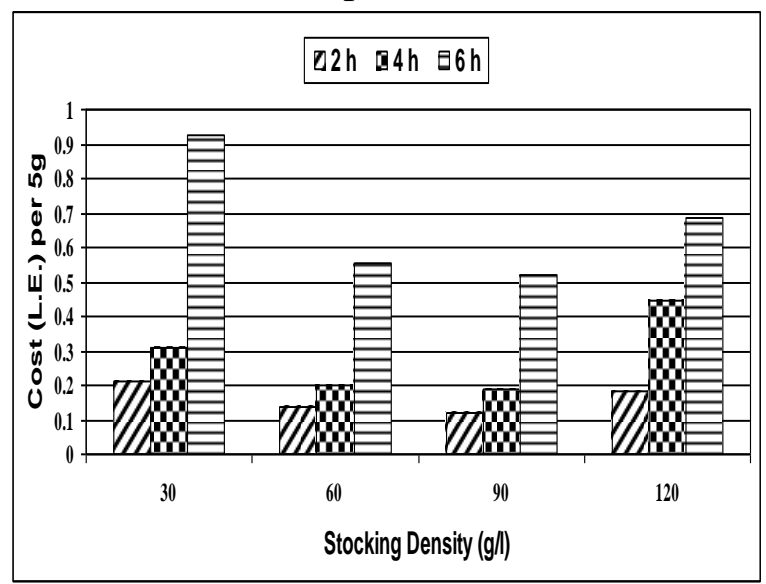

Figure 5: Effect of study parameters on the total cost per 5g. for live fry with polyethylene bags.

The total cost per 5g. for live fry was decreased from 0.18 to 0.09 L.E and from 0.21 to 0.18 L.E through increasing stocking density from 30 to 120 $\mathrm{g} / \mathrm{l}$; meanwhile it was decreased with $30 \mathrm{~g} / \mathrm{l}$ stocking density from 0.18 to 0.36 L.E and from 0.21 to 0.93 L.E through increasing transport duration from 2 to $6 \mathrm{~h}$. under both systems of aeration.

\subsection{Cost Analysis for Cylindrical Containers:}

Fig. 6 depicts the cost incurred using cylindrical container under different stocking densities, transport durations and aeration methods. It can be concluded from these figures that the cost associated with one container transport is increasing by increasing transport duration. It is interesting to notice that the cost incurred using pure oxygen supply was lower than that incurred using atmospheric air supply but with a little margin. This result is attributed to the cost of air pump and tubing under atmospheric air supply. The total cost per $5 \mathrm{~g}$. for live fry was increased from 0.19 to 0.11 L.E and from 0.21 to 0.11 L.E through increasing stocking density from 30 to $120 \mathrm{~g} / \mathrm{l}$; meanwhile it was increased from 0.19 to 0.39 L.E and from 0.21 to 0.54 L.E with increasing transport duration from 2 to $6 \mathrm{~h}$. with $30 \mathrm{~g} / \mathrm{l}$ stocking density under both systems of aeration. 
Pure oxygen

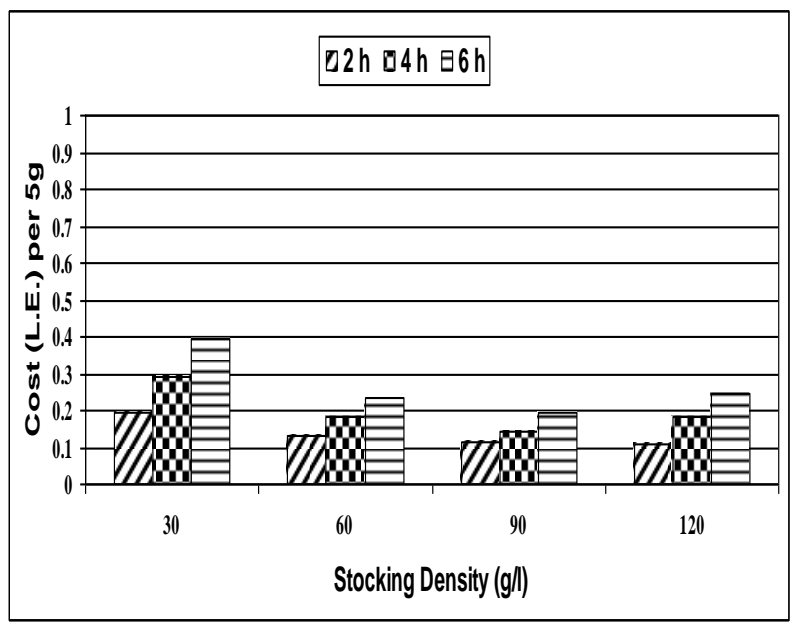

Atmospheric air

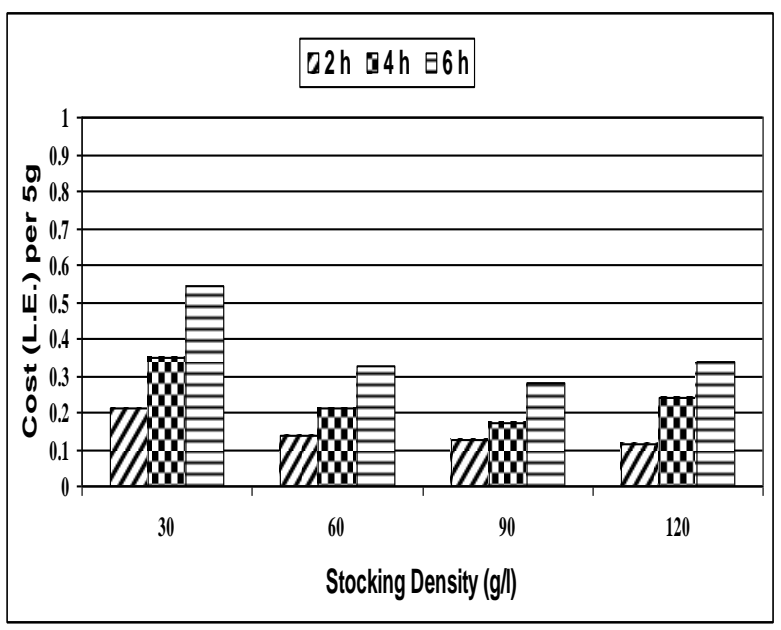

Figure 6: Effect of study parameters on the total cost per 5g. for live fry with cylindrical container.

\subsection{Cost Analysis for Cuboids Container:}

Fig. 7 depicts the cost incurred using cuboids container under different stocking densities, transport durations and aeration methods. It can be concluded from these figures that the cost associated with one container transport is increasing by increasing transport duration. It is interesting to notice that the total cost incurred using pure oxygen supply was lower than that incurred using atmospheric air supply but with a little margin. This result is attributed to the cost of air pump and tubing under atmospheric air supply. The total cost per $5 \mathrm{~g}$. for live fry was increased from 0.20 to 0.10 L.E and from 0.21 to 0.11 L.E through increasing stocking density from 30 to $120 \mathrm{~g} / \mathrm{l}$; meanwhile it was increased from 0.20 to 0.43 L.E and from 0.21 to 0.57 L.E with increasing transport duration from 2 to $6 \mathrm{~h}$. with $30 \mathrm{~g} / \mathrm{l}$ stocking density under both systems of aeration. 
Pure oxygen

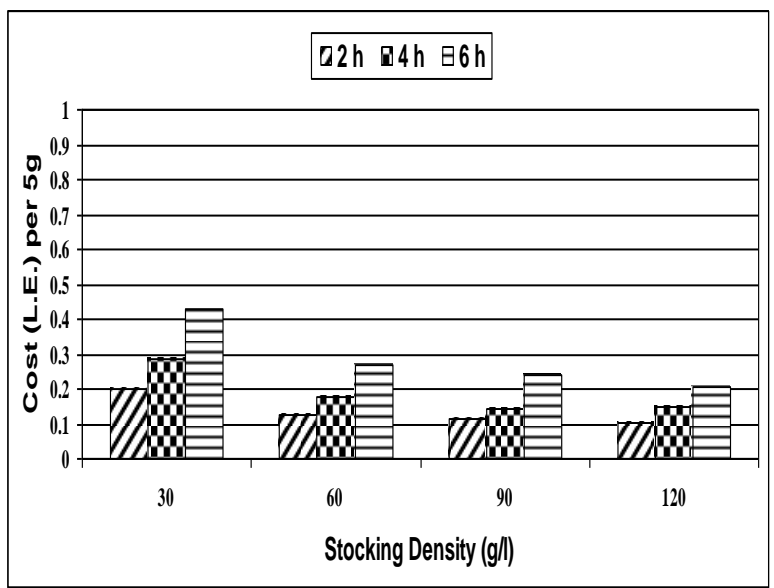

Atmospheric air

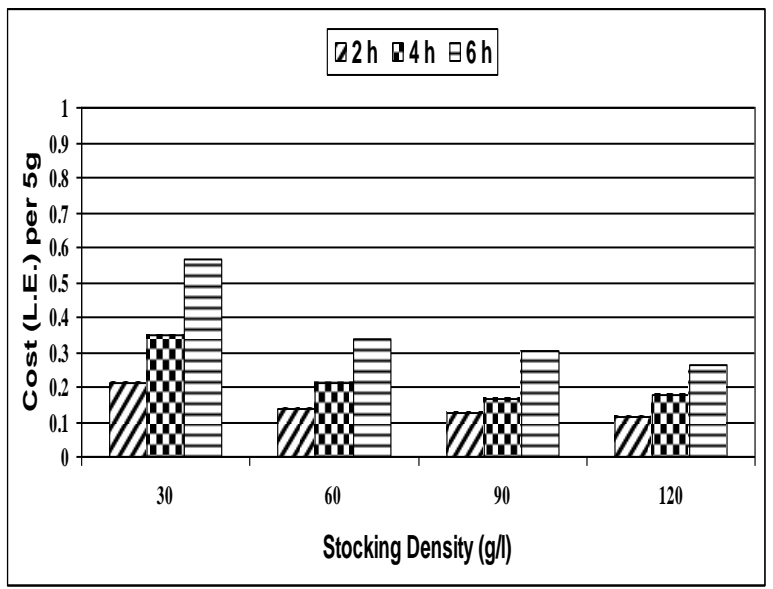

Figure 7: Effect of study parameters on the total cost per $5 \mathrm{~g}$. for live fry with cuboids container.

Table (1): Effect of stocking density, duration of transportation, methods of aeration and different containers shapes on water quality, survival ratio and transportation cost.

\begin{tabular}{|c|c|c|c|c|}
\hline \multirow[b]{2}{*}{ parameters } & \multicolumn{4}{|c|}{$\begin{array}{c}\text { Water quality measurement, survival rate and } \\
\text { transportation cost }\end{array}$} \\
\hline & $\begin{array}{c}\text { Oxygen } \\
\text { concentration } \\
(\mathrm{g} / \mathrm{l})\end{array}$ & $\mathrm{pH}$ values & $\begin{array}{c}\text { Ammonia } \\
\text { concentration } \\
(\mathrm{g} / \mathrm{l})\end{array}$ & $\begin{array}{l}\text { Survival } \\
\text { ratio }(\%)\end{array}$ \\
\hline Stocking density $=30 \mathrm{~g} / \mathrm{l}$ & $3.76^{\mathrm{a}}$ & $6.62^{\mathrm{a}}$ & $3.24^{\mathrm{a}}$ & $77.25^{\mathrm{a}}$ \\
\hline Stocking density $=60 \mathrm{~g} / \mathrm{l}$ & $3.15^{b}$ & $6.77^{\mathrm{b}}$ & $3.93^{\mathrm{b}}$ & $74.92^{b}$ \\
\hline Stocking density $=90 \mathrm{~g} / \mathrm{l}$ & $2.52^{\mathrm{c}}$ & $6.90^{\mathrm{c}}$ & $4.39^{\mathrm{c}}$ & $69.10^{\mathrm{c}}$ \\
\hline Stocking density $=120 \mathrm{~g} / \mathrm{l}$ & $2.88^{\mathrm{d}}$ & $7.04^{\mathrm{d}}$ & $5.14^{\mathrm{d}}$ & $57.41^{\mathrm{d}}$ \\
\hline Transportation duration $=2 \mathrm{~h}$ & $3.62^{\mathrm{a}}$ & $6.74^{\mathrm{a}}$ & $3.00^{\mathrm{a}}$ & $81.52^{c}$ \\
\hline Transportation duration $=4 \mathrm{~h}$ & $2.88^{\mathrm{b}}$ & $6.83^{b}$ & $4.15^{b}$ & $71.77^{\mathrm{b}}$ \\
\hline Transportation duration $=6 \mathrm{~h}$ & $2.13^{\mathrm{c}}$ & $6.92^{c}$ & $5.38^{\mathrm{c}}$ & $55.72^{b}$ \\
\hline Containers shape $=$ polyethylene bags & $2.40^{\mathrm{b}}$ & $6.86^{\mathrm{a}}$ & $3.64^{\mathrm{c}}$ & $71.90^{\mathrm{a}}$ \\
\hline Containers shape $=$ cylindrical & $3.21^{\mathrm{a}}$ & $6.77^{\mathrm{b}}$ & $4.23^{\mathrm{b}}$ & $70.89^{\mathrm{a}}$ \\
\hline Containers shape $=$ cuboids & $3.03^{\mathrm{a}}$ & $6.86^{\mathrm{a}}$ & $5.14^{\mathrm{a}}$ & $66.21^{\mathrm{b}}$ \\
\hline System aeration $=$ pure oxygen & $3.51^{\mathrm{a}}$ & $6.77^{\mathrm{a}}$ & $3.38^{\mathrm{a}}$ & $77.73^{\mathrm{a}}$ \\
\hline System aeration $=$ air atmospheric & $2.25^{b}$ & $6.89^{b}$ & $4.98^{\mathrm{b}}$ & $61.61^{\mathrm{b}}$ \\
\hline
\end{tabular}




\section{CONCLUSIONS}

Analysis of the results of the current research can led to the following conclusions:

1. Oxygen concentration decreased in all treatments regardless of aeration system or stocking density used. Stocking density of 30 $\mathrm{g} / \mathrm{l}$ and $2 \mathrm{~h}$ transport duration resulted in the highest oxygen concentration under different aeration systems and container shapes used.

2. $\mathrm{pH}$ values increased in all treatments regardless of aeration system or stocking density used. Stocking density of $30 \mathrm{~g} / \mathrm{l}$ and $2 \mathrm{~h}$ transport duration resulted in the lowest $\mathrm{pH}$ values under different aeration systems and container shapes used.

3. Ammonia concentration increased in all treatments regardless of aeration system or stocking density used. Stocking density of 30 $\mathrm{g} / \mathrm{l}$ and $2 \mathrm{~h}$ transport duration resulted in the lowest ammonia concentration under different aeration systems and container shapes used.

4. Survival ratio decreased in all treatments regardless of aeration system or stocking density used. Stocking density of $30 \mathrm{~g} / \mathrm{l}$ and $2 \mathrm{~h}$ transport duration resulted in the highest survival ratio under different aeration systems and container shapes used.

5. Oxygen concentration in water in closed system, i.e., polyethylene bags, was higher than that of open systems, i.e., cylindrical or cuboids containers. This could be attributed to the higher solubility of oxygen under closed systems.

6. $\mathrm{pH}$ values of water during transport of silver carp fry in polyethylene bags was lower than that noticed using cylindrical containers which was lower than that measured using cuboids containers.

7. Total ammonia concentration in water during transport of silver carp fry in polyethylene bags was lower than cylindrical shape which was lower than cuboids shape. 
8. Survival rate of silver carp fry in polyethylene bags was better than that in cylindrical and cuboids containers. This result is attributed to the nervous behavior of fries during transportation. Fry get scared from shaking and jumps in containers. Soft containers resulted in fewer casualties than hard ones.

9. Total cost incurred using polyethylene bags was lower than that incurred using containers under all stocking densities, transport durations and aeration methods.

10. Total cost incurred using pure oxygen supply was higher than that incurred using atmospheric air supply in polyethylene bags under all stocking densities and transport durations. This result was reversed in containers.

It can be recommended that using polyethylene bags with stocking density of fry $30 \mathrm{~g} / \mathrm{l}$ and pure oxygen supply at 2 hours duration of fry transportation are better than using open containers at the same treatment due to:

1- Survival rate using bags was higher than others.

2- Water quality was better under bags treatments.

3- Total cost associated with using polyethylene bags was lower than that associated with other containers.

\section{REFERENCES}

Awady, M. N. (1978) Engineering of tractors and agricultural machinery, Text Bk., Col. Ag., Ain for Shams U., 5th Ed.: 164-167. (In Arabic)(Updating 1998).

Boyd, C. E. (1982) Water Quality Management Ponds Fish Culture. Elsevier, Amsterdam, $318 \mathrm{pp}$.

Boyd, C. E. and Watten, B. J. (1989) Aeration system in aquaculture, CRC Critical Reviews in Aquatic Sciences, 1:425-472.

Chona, B. E. and Marietta, N. D. (2003) Transport of hatchery-reared and wild grouper larvae, Epinephelus sp. Aquaculture 219, 279-290.

Golombieski, J. I.; Silva, L. V. F.; Baldisserotto, B. and da Silva, J. H. 
S. (2003) Transport of silver catfish (Rhamdia quelen) fingerling at different times, load densities, and temperatures. Aquaculture 216, 95-102.

Gomes, L. C.; Golombieski, J. I.; Chippari-Gomes, A. P. and Baldisserotto, B. (1999) Effect of salt in the water for transport on survival and on $\mathrm{Na}+$ and $\mathrm{K}+$ body levels of silver catfish, Rhamdia quelen, fingerlings. J. Appl. Aquacult. 9(4), 1-9.

Hamza, A. K. (1988) Fish culture development in Egypt. Bamidgeh, 41(2): 43-49.

Lawson, T. B. (1995) Fundamental of Aquacultural Engineering. Elsiver Scientific Publishers, Amsterdam.

Nemcosk, J.; Gyore, K.; Olah, J. and Boross, L. (1984) Effect of ammonia on blood glucose and catecholamine level, GOT, GPT, LDR enzyme activity and respiration of fishes. Symposia. Biolo. Hungriaa. 23:209-217.

Ng, W. J.; Kho, K.; Ho, L. M.; Ong, S. L.; Sim, T. S.; Tay, S. H.; Goh, C. and Cheong, L. (1992) Water quality within a recirculating system for tropical ornamental fish culture. Aquaculture, 103:123134.

Pavlidis, M.; Angellotti, L.; Papandroulakis, N. and Divanach, P. (2003) Evaluation of transportation procedures on water quality and fry performance in red porgy (Pagrus pagrus) fry. Aquacuture 218, 187-202.

Piper, R. G.; McElwain, I. B.; Orme, L. E.; McCraren, J. P.; Fowler, L. G. and Leonerd, J. R. (1982) Fish Hatchery Management United States Department of the Interior, Washington, DC, 517pp.

Thurston, R. V.; Pillips, G. R. and Russo, R. C. (1981) Increased toxicity of ammonia to rainbow trout (Salmo gairderi) resulting from reduced concentration of dissolved oxygen. Can J. Fish. Aquat. Sci., 38:983-988.

FAO (2009) National Aquaculture Sector Over view in Egypt (http://www.fao.org/fishery/countrysector/naso_egypt/en) 


\section{الملخص العربيى \\ تقييم الطرق المختلفة لنقل زريعة أسماك المبروك الفضئى وتأثير ها على جودة المياه ونسبة الإعاثة الميرو}

السادات إبراهيم على عبد العال" عبد الله مصطفى محمد قثطة" محمد السيد إسماعيل رضوان"* محمود محمد السعيد سليمان**

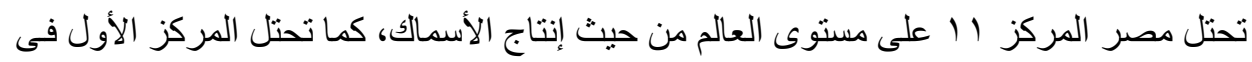

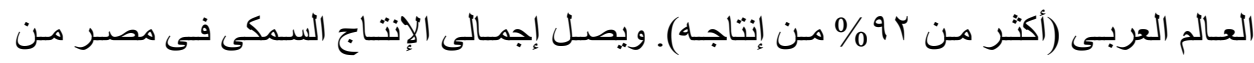

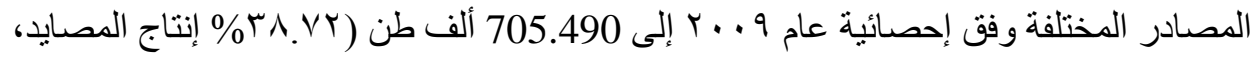

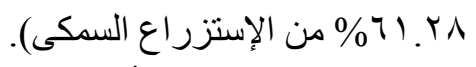

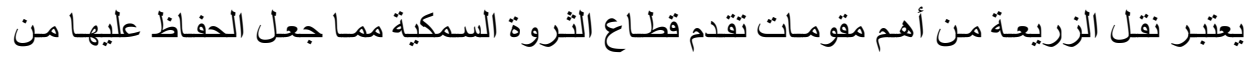
المنطلبات الضرورية للثروة السمكية.

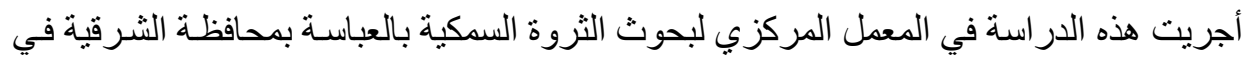

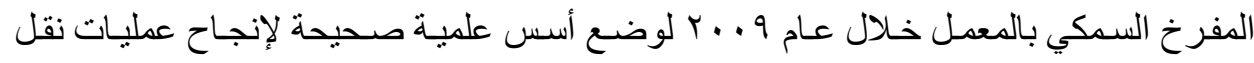

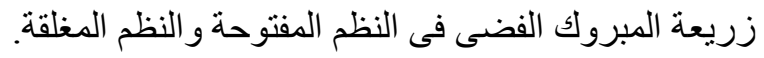
وقد تم در اسة المعاملات التالية:

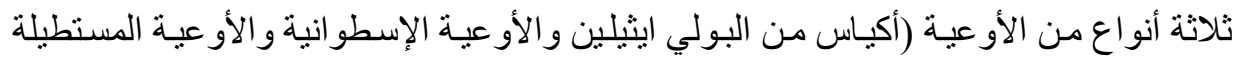

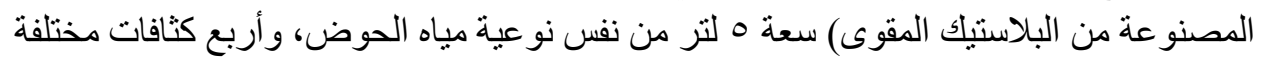

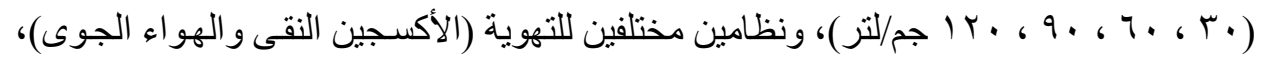

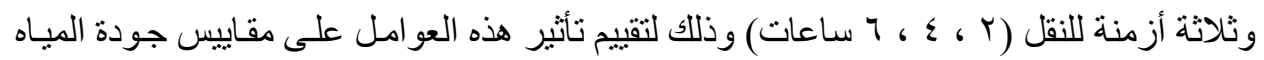
وتقليل نسبة الفاقد أثناء النقل.

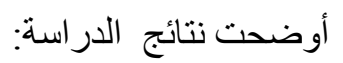

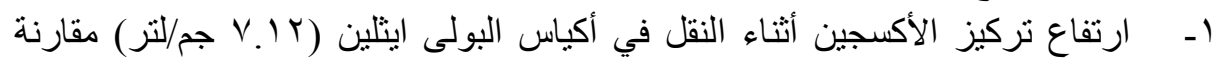

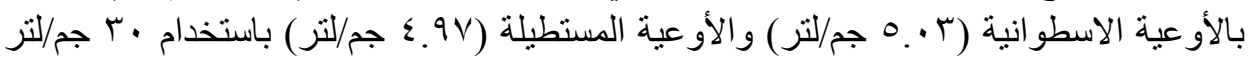

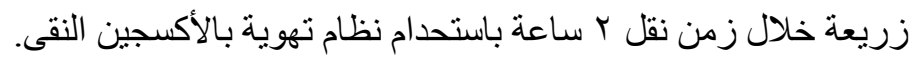

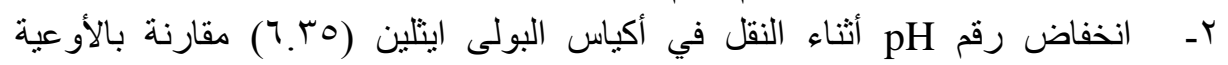

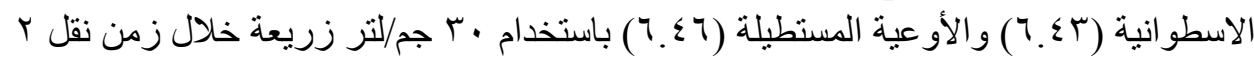
ساعة باستحدام نظام تهوية بالأكسجين النقى.

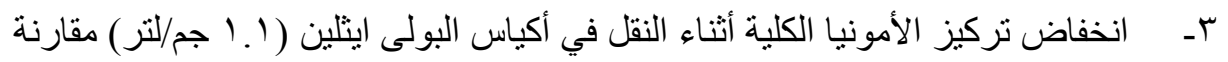

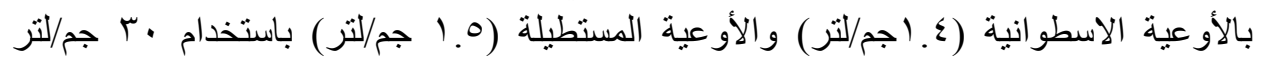

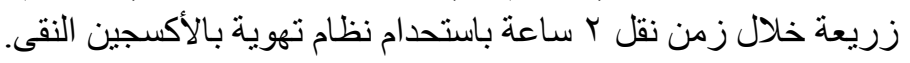

"أستاذ مساعد بقسم الهندسة الزراعية، كلية الزراعة، جامعة الزقازيق.

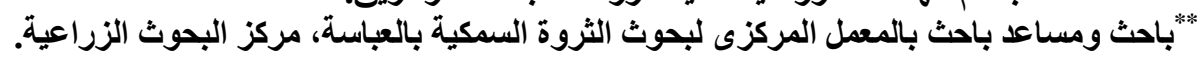




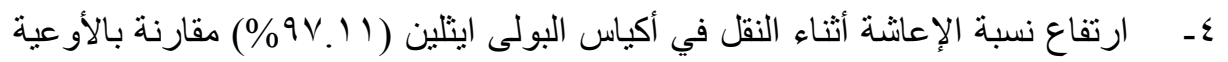

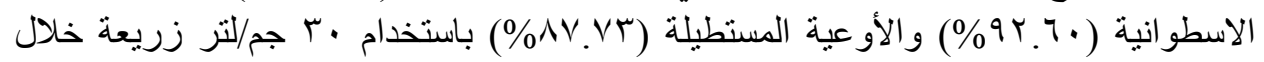
زمن نقل r ساعة باستحدام نظام تهوية بالأكسجين النقى. (الأهة 0ـ انخفاض التكاليف الكلية عند استخدام أكياس البولى ايثلين (9 . . جنيه) أقل بالمقارنة

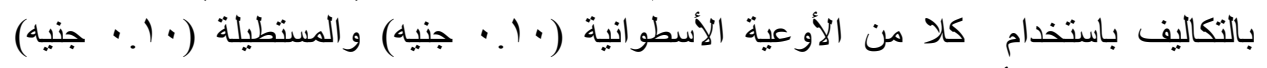
باستخدام مصدر للأكسجين النقى خلال زمن نقل ساعتين. توصى الار اسة عند نقل زريعة المبروك الفضى: - - - استخدام أكياس البولى ايثلين. r - استخدام كثافة تحميل • ب جم/لتر. ب- استخدام مصدر تهوية الأكسجين النقى. ع- الزمن المناسب لعملية نقل زريعة المبروك الفضى ب ساعة.

وذللك لإنخفاض قيمة pH وانخفاض تركيز الأمونيا الكلية و التركيز المو ائم من الأكسجين مما

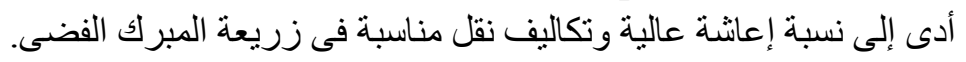

